\title{
Regional geological and tectonic structures of the Sirt basin from potential field data
}

\author{
Ahmed. S. Saheel ${ }^{1}$, Abdul Rahim Bin Samsudin², Umar Bin Hamzah² \\ ${ }^{1}$ Libyan Petroleum Institute (LPI), Triploi-Libya, P.O.Box 6431. \\ ${ }^{2}$ School of Environment and Natural Resource Sciences, Faculty of Science and Technology, \\ Universiti Kebangsaan Malaysia, 43600 Bangi, Selangor.
}

\begin{abstract}
The area involved in this study is Sirt basin, which is located in the north central part of Libya within the bounder's $27^{\circ} \mathrm{N}-33^{\circ} \mathrm{N}$ and $16^{\circ} \mathrm{E}-22^{\circ} \mathrm{E}$. The study involves the analysis of gravity and magnetic data to delineate structures and faults and to locate any major structures. The produced Bouguer gravity map shows prominent NW-SE and N-NW trends. Isostatic residual map is characterized by a dominant NW- SE trend in the study area. This is clearly evident in the isostatic residual. The main trending anomalies are in the northern and southeastern parts of the study area with NW-SE orientation. A strong NW-SE trend is truncated by E-W trending in the southeastern and southwestern parts of the area. This is consistent with change of tectonic zones. The magnetic expression in the northern part of Ajdabiya trough is characterized by NW-SE trending structures which coincide with late Cretaceous structures of the Sirt basin, while the southern part is characterised by NE-SW trending features which coincide with a late Paleozoic trend. The northern part of the Ajdabiya trough is separated from the southern part by a prominent NE-SW lineament that is expressed in both the gravity and magnetic data. It is interpreted as a basement fault, which separates a thicker southern crust from a thinner northern crust. The high gravity anomaly within the northern part of the Ajdabiya trough is interpreted as a result of mantle upwelling which caused thinning of the continental crust beneath the northern part of the Ajdabiya trough. The Total horizontal derivative results of Gravity, 3D Euler Deconvolution of gravity and magnetic data magnetic anomalies produced features trending similar to the positions of tectonic and geological information from the Sirt basin. High gradient values delineate NNW-SSE to N-S and NW-SE trends which mark the faulted southwestern, southern, northern and central boundaries of the basin, respectively. New faults with orientations NNW-SSE trends along the southwestern flank of the Sirt basin and is truncated by E-W faults dividing it into segments. Strong N-S lineaments occur over the southern and central part of study area and are well indicated by the 3D Euler Deconvolution. From this study the 3D Euler Deconvolution provides very useful information of the rift structures.
\end{abstract}

Keywords: Geological and tectonic, Bouguer gravity map, field data

\section{INTRODUCTION}

The area involved in this study is Sirt basin, which is located in the north central part of Libya. It covers a total surface area of almost five hundred thousand square kilometers (Fig.1). Even though petroleum exploration activities in Libya started more than 50 years ago, little is known about the structure of this basin. The present study used gravity and magnetic data provided by Libyan Petroleum Institute (LPI) and Geodetic Survey Department of Libya (SDL). 112,120 gravity points were assembled of which 2,299 points were from Shell Oil Company, 952 points were from SDL and 108,869 stations were from LPI and 2000 magnetic lines were used in this study. As discussed below, they were recalculated using a density of $2.67 \mathrm{~g} / \mathrm{cm}^{3}$ and using 1980 Gravity Formula in producing a Bouguer gravity map of the Sirt basin. The main purpose of this study is to compile the available geology, gravity and magnetic data in the Sirt basin in order to understand the tectonic evolution of the basin better and to construct the tectonic map of the study area.

Geological setting and Tectonic elements: During the Early Cretaceous (Aptian), organic movement affected most of North Africa. Africa was separated from Asia along the red sea graben (Extension). This movement produced the rifting of Sirt basin (Anketell, 1996 and Hallett, 2002). The post Cretaceous faulting 
system was generated by sinistral and dextral strike slip movement of Sahara platform west ward along the Mediterranean Sea (Tethys). The formation of NWSE faulting system of horst and graben patterns started in Early Cretaceous and culminated during the Tertiary. In the beginning of the Late Cretaceous (Cenomanian), the sea entered the basin and only the major horsts in Sirt basin were emergent (Fig.2). Throughout the Late Cretaceous, the sea continued to advance south wards and by the end of Maastrichtian age only a few scattered crests remained above the sea level as isolated island
(Duronio and Colombi, 1983). The period from Maastrichtian to Upper Eocene was characterized by macro basin subsidence and continued transgression with minor regression. Source rocks, reservoirs and seals were formed during this period (Hallett and El Ghoul, 1996).

The final structure stage developed the traps and migration of hydrocarbon from source rocks and accumulated in the different reservoirs during Early Oligocene and Pleistocene Epoch (Baird, Aburawi and Bailey, 1996).

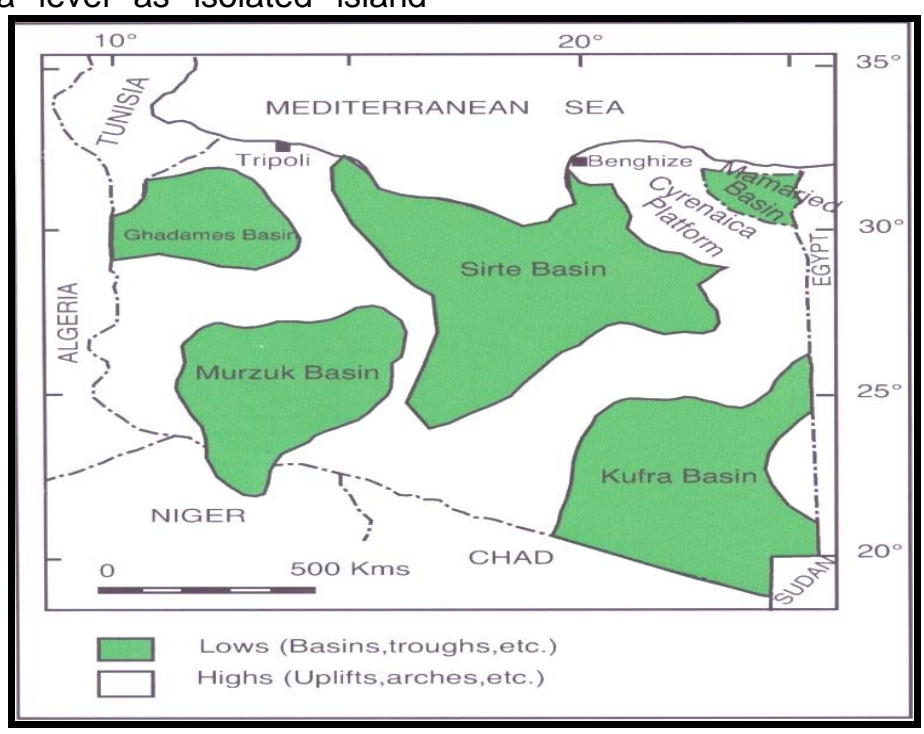

Fig.1 Location Map of the Basins in Libya (after Shah et al., 1993)

Subsurface Stratigraphic Succession: The sediments of Sirt Basin had been classified in to Pre-rift, Syn-rift and Post-rift. The Pre-rift and Post-rift sediments were dominated by clastic, whereas the Syn-rift sediments were dominated by carbonate (Fig.3). The primary reservoirs of Sirt basin within concessions included the Cambro- Ordovician to Cretaceous Gargaf formation, the Upper Cretaceous sand and carbonates, the Paleocene carbonates, the Eocene carbonate and Oligocene sandstone.

The Pre Rifting Sediments (Cambro - Ordovician): The Cambro - Ordovician sediments were represented by Gargaf Formation which consisted of continental sandstone, conglomerate and shale beds (Goudarzi, 1970, 1980). The Gargaf Formation bounded by unconformable boundaries and overlain by Bahi Formation and underlain by Basement igneous rocks.

The Syn Rifting Sediments (Late Cretaceous-Late Eocene): This stage represented the Late CretaceousLate Eocene sediments (basin fill stage). These sediments were mainly marine of different depositional environments as result of fluctuation in sea level either raising (Transgression) or lowering (Regression), controlled by NW - SE oriented horst and graben structures. The Cretaceous sediments unconformable over lay the Gargaf quartzite Formation. These sediments represented Bahi sandstone, Waha, Sirt Shale and Kalash Formations. The Bahi, Waha and Arshad were the principal reservoirs while the Sirt Shale Formation was the source rock (Parsons and others, 1980; Gumati and Schamel, 1988; Montgomery, 1994; El Alami, 1996; Ghori and Mohammed, 1996; Mansour and Magairhy, 1996; Macgregor and Moody, 1998; Ambrose, 2000). The Kalash Formation was widespread in concessions and acted as a cap rock in some places of central Sirt basin. The Tertiary sediments represented Hagfa Shale Formation which acted as source rock for Tertiary reservoirs in the Sirt Basin (Thomas, 1995). The Hagfa Formation overlain by succession of carbonate, shale, dolomite and evaporate.

The Post Rifting Sediments: This stage represents the Oligocene - Miocene sediments (Arida sandstone Formation), which was mainly shallow marine (Tidal 
to supra tidal environment) as result of regional lowering in the sea level (Regression). All those

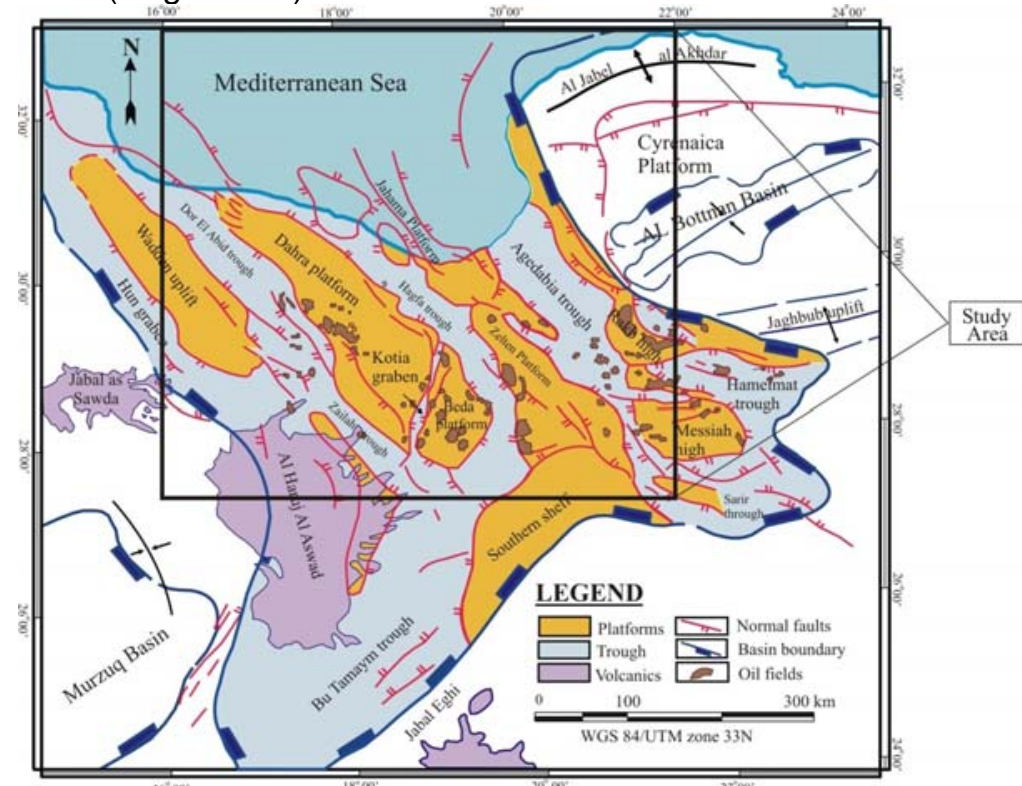

Fig.2 Tectonic elements and Geologic provinces of Sirt basin.

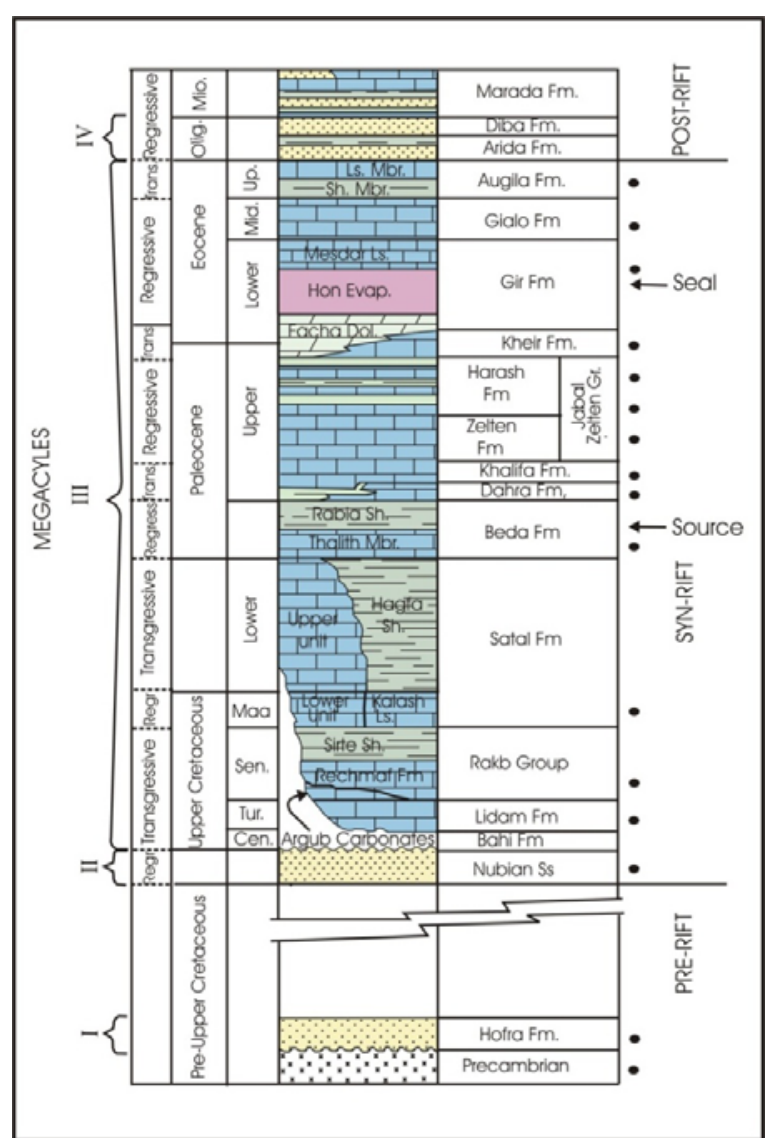

Fig.3 Stratigraphic section of Sirt Basin (modified after Barr and Weegar, 1972; Montgomery, 1994). 
Am. J. Sci. Ind. Res., 2010, 1(3): 448-462

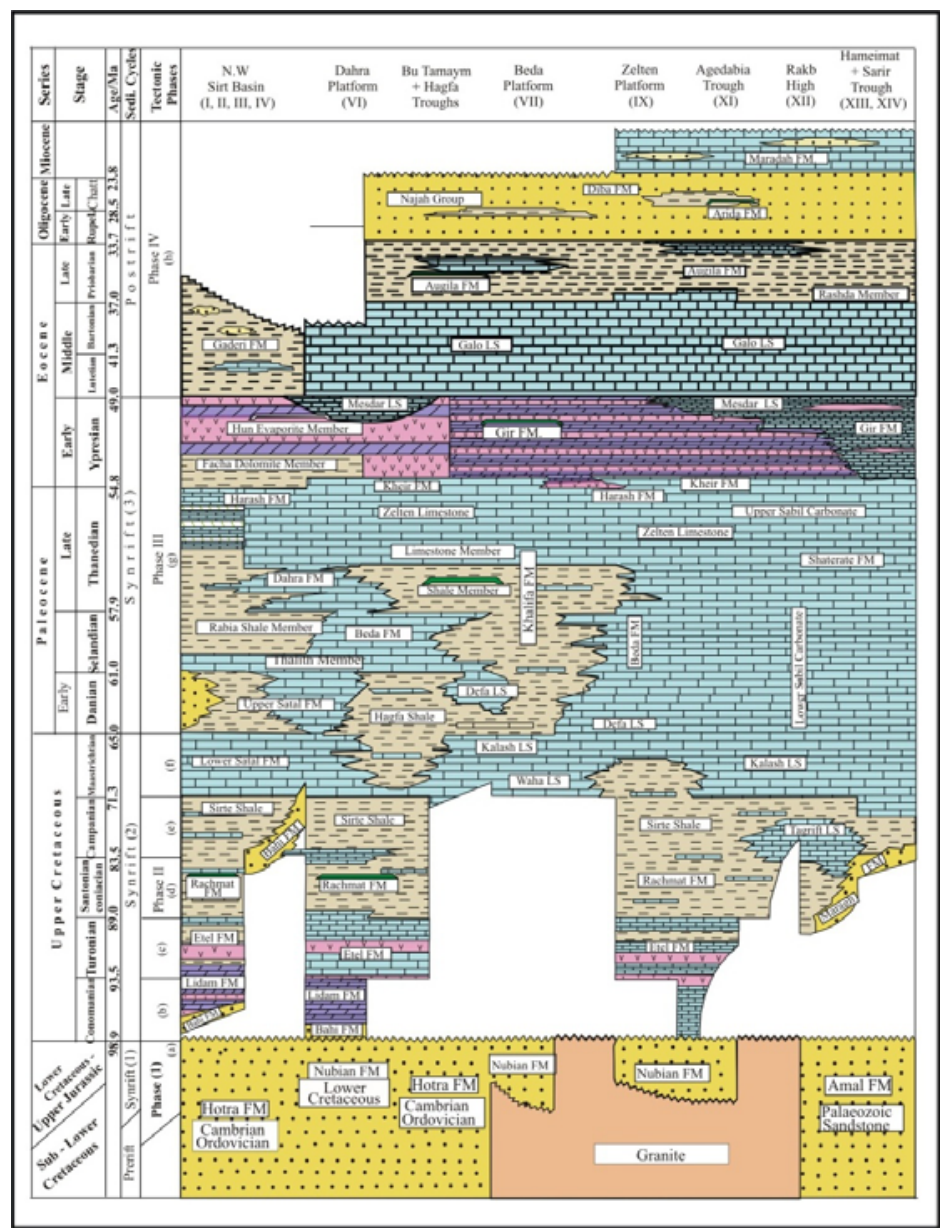

Fig.4 Illustrating Generalized Stratigraphy and Tectonic Phases in the Sirt Basin (nomenclature after Barr and Weegar, 1972).

\section{DATA SOURCES AND METHODOLOGY}

Gravity and magnetic data: The potential field data (gravity and magnetic) used in this research were obtained from different sources. The gravity data enabled the interpretation to be extended over large areas of Sirt basin. The Libyan Gravity Project (LGP) compiled all available onshore gravity data for the whole Libya. The gravity data for Sirt basin were recently updated using the latest validation technology. The gravity data was gridded at a cell size of 2 minute (approximately $4 \mathrm{~km}$ ). In the present study a total of 112,120 gravity points were assembled along survey line shown in Fig.5. They were recalculated by using a density $2.67 \mathrm{~g} / \mathrm{cm}^{3}$ and using 1980 gravity formula to produce a Bouguer gravity map of the study area. Rock densities used in the gravity reduction analysis were taken from different number of sources (Saheel, 1995, Suleiman, 1994 and Essed, 1978). All the gravity data had been tied to the Geodetic Reference System 1980 (GRS 80), using formula (Moritz, 1984). The African Magnetic Map (AMMP) was a compilation of all available airborne, ground and marine magnetic data for the whole of Africa from Getech et al., 2000. The data, which cover a variety of resolutions, vintages and types, were merged into a unified $1 \mathrm{~km}$ grid at a constant $1 \mathrm{~km}$ elevation above terrain (Fig.6). International Geomagnetic Reference Field (IGRF) was removed from the original data using a computer program which was the Geosoft package software, 1994.

Bouguer gravity map: The variations in gravity anomalies were normally caused by variations in the density of subsurface rocks (Reynolds, 1997), and they usually indicated faults or lithological contacts. Bouguer gravity anomaly of Sirt basin was generally in good coverage and it showed gravity values between +24 and $-43 \mathrm{mGal}$. The Bouguer gravity 
map (Fig.7) indicated nine main positive and seven main negative trends; the nine positive areas were $P 1, P 2, P 3, P 4, P 5, P 6$, and $P 7$ in the north-eastern, central and southeast parts of the areas as shown in figure 7 with a NW-SE trends, (P8) with trend E-W, (P9) with tend $\mathrm{N}-\mathrm{S}$. The main negative anomaly zones (N1-N5) were in the northwest, Central, south, southwest and southeast parts of the study area trending NW-SE and was superposed by smaller N-S oriented anomalies, (N6, N7) with trends E-W.

Total Magnetic Intensity map (TMI): The Total Magnetic Intensity (TMI) map (Fig.8) reflected the major tectonic features in the Sirt basin. The southwest part of Sirt basin showed an extensive NW-trending anomalies (Fig.8, M1) interpreted as represented belt of mid Jurassic to Early Cretaceous volcanic/intrusive complexes occupying the Sirt Basin and its extension to the northwest. The Sirt trough, Ajdabiya trough and Sarir troughs were marked by negative or low values anomaly, whereas the central, southern and eastern parts of Sirt basin were marked by a regional positive high anomaly.

RTP Magnetics: The Geosoft package software, 2009 was used to reduce the pole (RTP) transformation of an anomaly in the Fourier domain. The RTP aeromagnetic anomaly map (Fig.9) shows that both low and high frequency anomalies characterized the magnetic field in the study area. The elongated positive magnetic anomaly with a value of 165 NT was observed over the location of southwest study area. It was characterized by high frequency and high amplitude. Such magnetic anomaly is associated with metavolcanics which are mainly characterized by high magnetic susceptibilities. This magnetic anomaly was bounded by steep magnetic gradients, which indicated the presence of two faults, trending in the NW-SE direction (Aqaba trend). The Sirt trough, Ajdabiya trough and Sarir troughs were marked by negative anomaly. A strong NNE-SSW trending anomaly truncated by the N-S trending were observed in the north-eastern and south-western parts of study area. The effectiveness total horizontal derivative magnetic data technique depends on the difference in wave number content of deep-source anomalies relative to shallow-source anomalies. Interesting results can be obtained in the case of data set with different wave number.

Interpretation of the potential field maps: Three methods were employed in the analysis of gravity and magnetic data from the Sirt Basin in order to delineate lithological boundaries and faults. These were the horizontal derivative, residual gravity anomaly and 3D Euler deconvolution techniques. Their theory and advantages were briefly discussed. The software used for data processing and presentation in this study was the Geosoft PC program set.

Horizontal derivative: The horizontal derivative (HD) method has been used for many years to locate density boundaries from gravity data (cordell,1979), density and susceptibility boundaries from magnetic ( as Pseudogravity) data (cordell and Grauch, 1985). These authors discussed a technique to estimate the location of abrupt lateral changes in magnetization or mass density of upper crust rocks. The method is normally applied to gridded data rather than profiles. Maximum magnitudes of horizontal gravity gradient normally occur above geological boundaries such as faults or steeply dipping lithological boundaries. Areas of steep lateral gradients have higher scalar amplitude values of horizontal gravity gradient (Blakely and Simpson, 1986). However, in the Sirt basin, lithological boundaries within the sedimentary strata were sub horizontal, therefore, horizontal gradient anomalies were most likely to be related to basin structures.

In applying this technique to a gridded dataset, the gridded gravity for each grid point ( $\left.x^{\prime} y\right)$ was determined. Then the gravity gradient function was calculated according to the following equation:

$$
\mathrm{f}=\sqrt{\left(\frac{\partial g}{\partial x}\right)^{2}+\left(\frac{\partial g}{\partial y}\right)^{2}}
$$

Where $\mathrm{f}$ is "total h horizontal gradient" , $(\delta g f \hat{\partial x})$ is the $\mathrm{x}$ derivative and $(\hat{\sigma} g / \hat{\delta} y)$ is the y derivative. The technique is influenced by a number of factors such as dip of discontinuity, data spacing, reliability of data and density contrast.

Shallow dipping faults were shown in a position shifted in a downdip direction (Grauch and Cordell, 1987; Hansen et al. 1987). In the Sirt basin, all faults were of the high angle type as indicated by seismic data (chapter 5) and hence, fault positions were not influenced greatly by this shortcoming. Faults close together are usually unresolved (Grauch and Cordell, op.cit). 
Am. J. Sci. Ind. Res., 2010, 1(3): 448-462

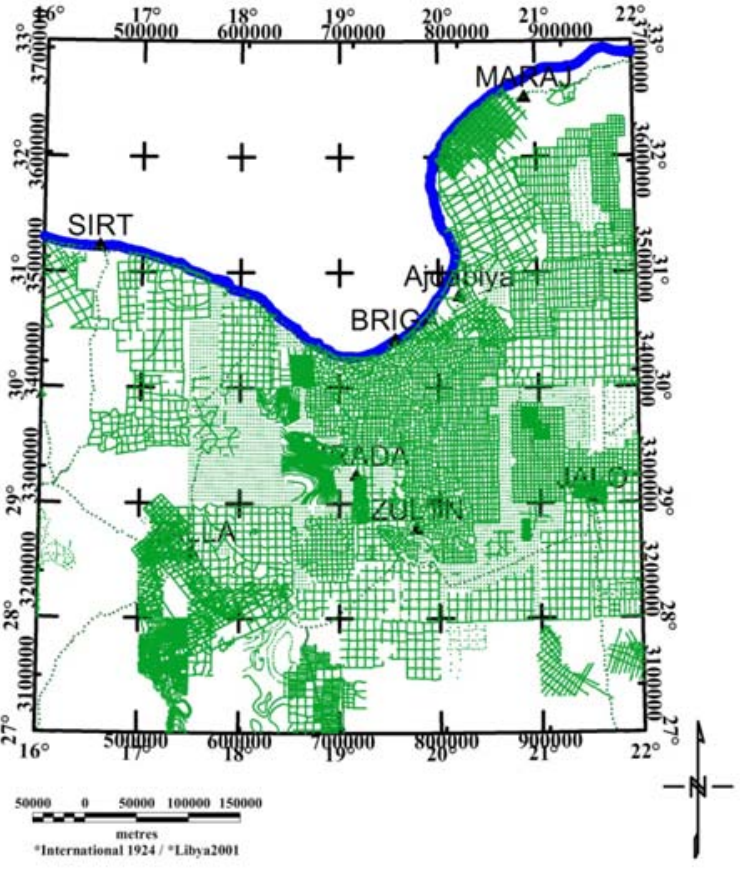

Fig.5 depicting gravity distribution in the Sirt basin and surrounding regions.

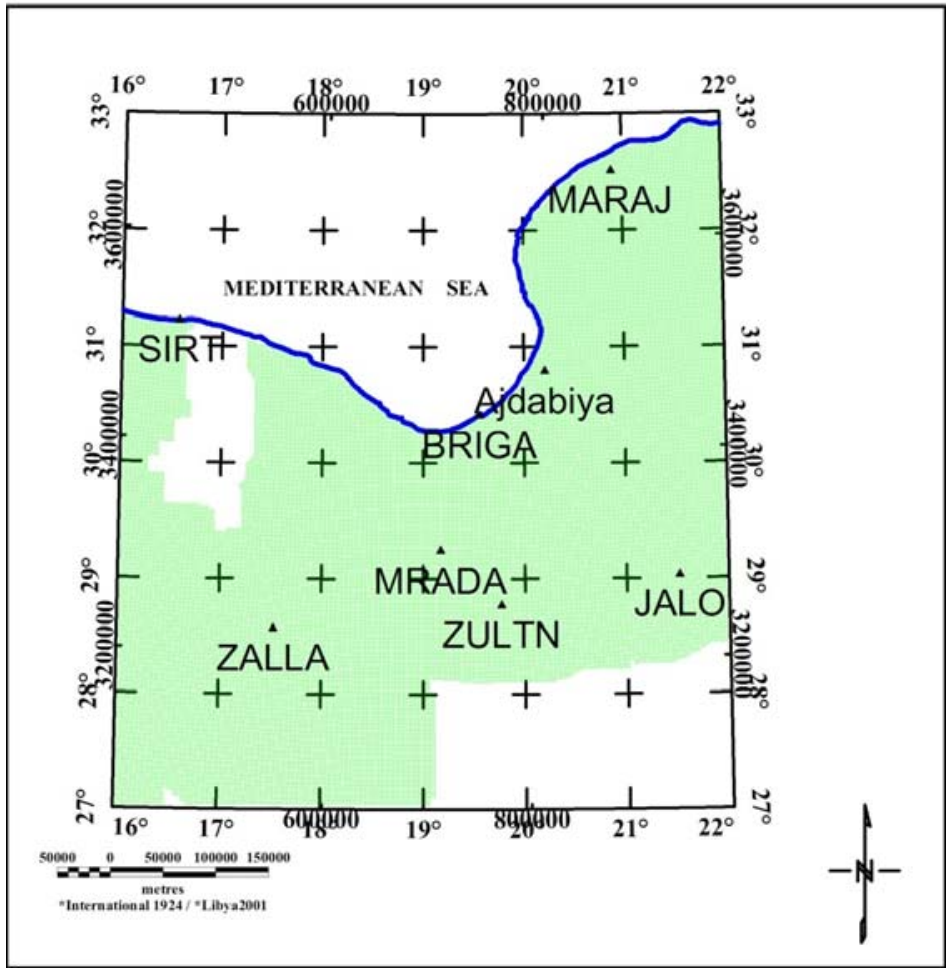

Fig.6. Map showing the Magnetic distribution in the Sirt basin. 


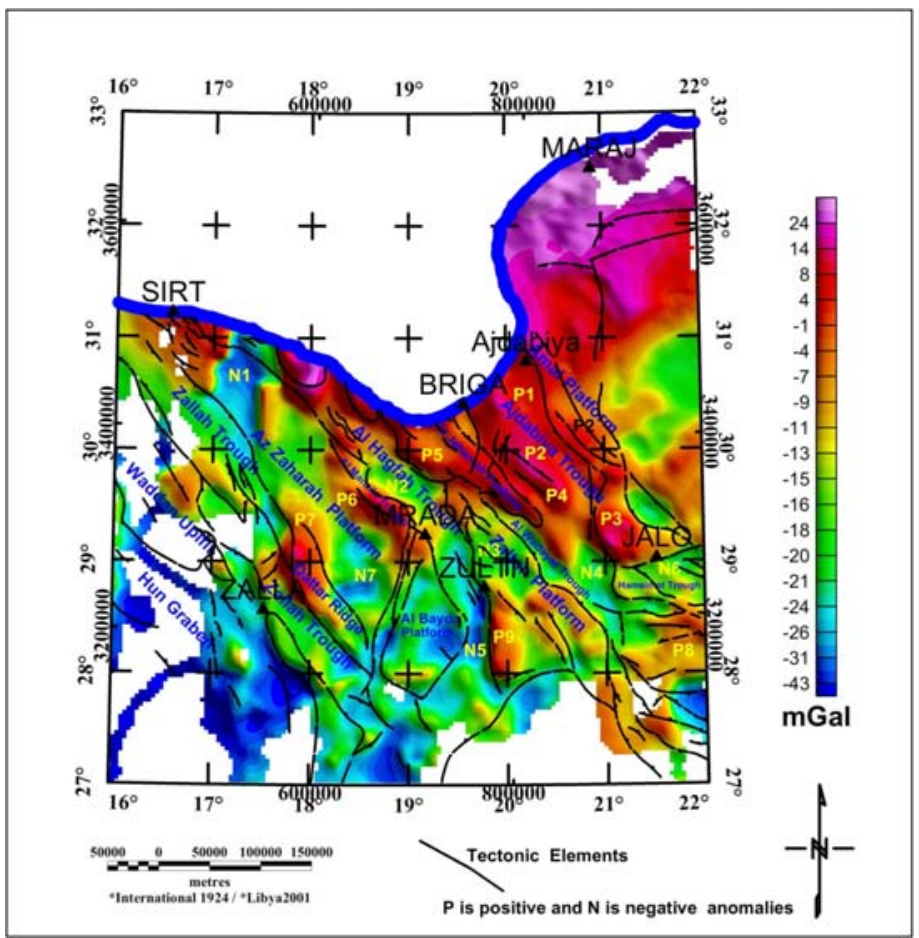

Fig.7 Bouguer gravity anomaly map of Sirt basin" Grid cell size $=\mathbf{4 0 0 0}$ meters".

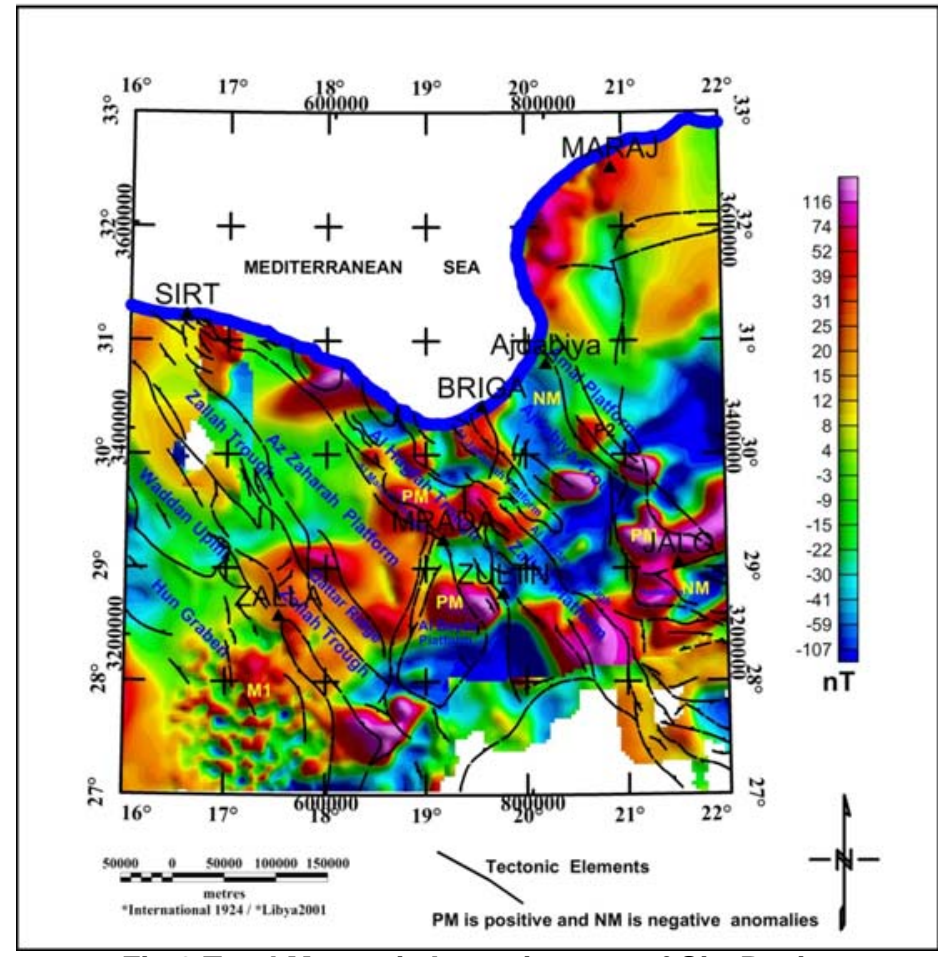

Fig.8 Total Magnetic Intensity map of Sirt Basin. 


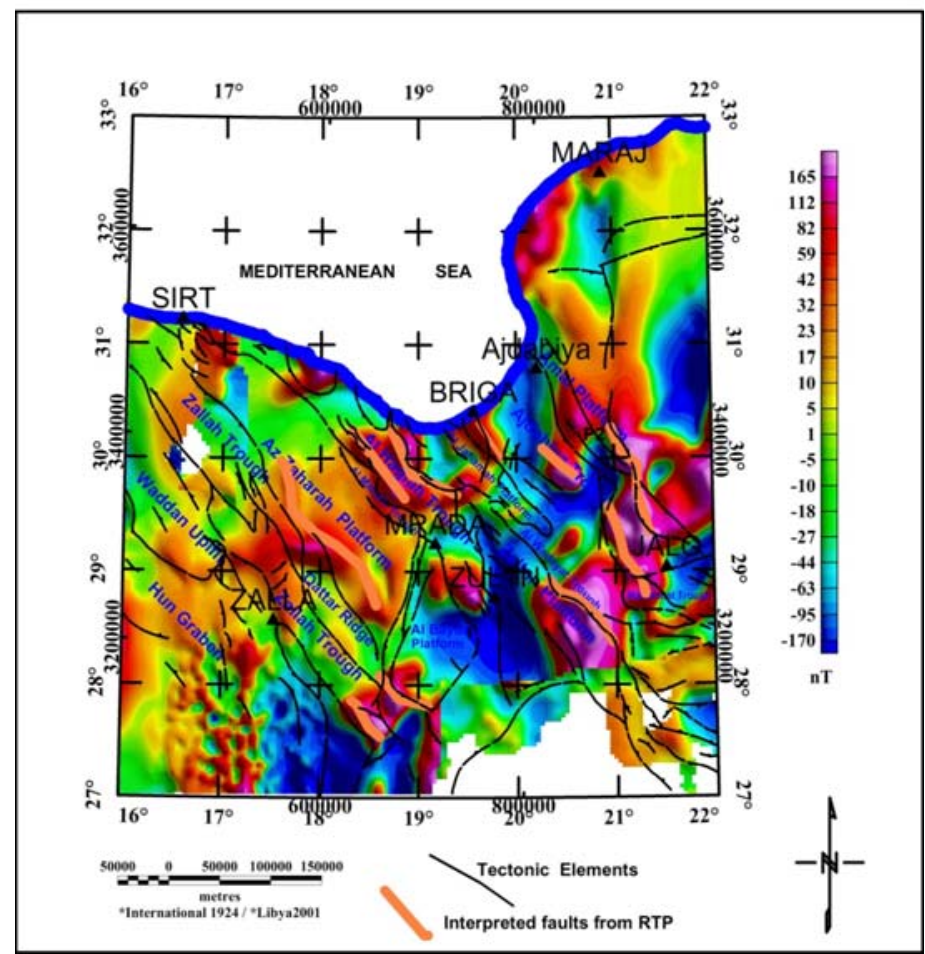

Fig.9 Reduction to the pole map of magnetic data in Sirt basin.

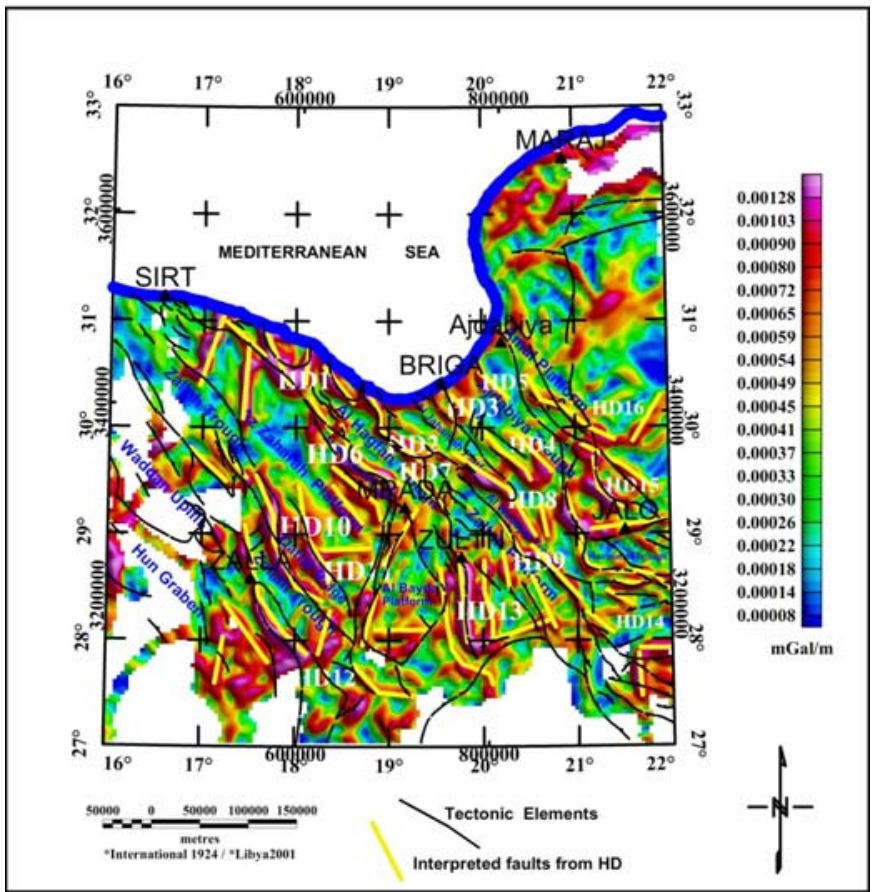

Fig.10. Total horizontal derivative map of Bouguer anomaly of Sirt Basin. HD represents strong gradient. 
Data spacing influences the horizontal derivative resolution significantly. This is obviously at its worst in areas of data gaps or wide grid spacing. In the Sirt basin, the average cover data spacing was about $4 x$ $4 \mathrm{~km}$ which was gridded to $2 \times 2 \mathrm{~km}$ and reasonable resolution was given. 'However, in some areas of the basin, especially the south and southeast, the data spacing was very widely spaced or absent. Hence these areas were not resolved and were left blank. The data reliability is important since a single point with false gravity value can produce strong gradients around it. Data checking is very important to eliminate such artifacts. Finally, the method cannot show all faults in the sequence, not if they are at least unassociated with sufficient density contrast.

The GEOSCFT (2009) program GRIDHDRV, which calculates either the amplitude of horizontal derivative vector, or the value of the derivative in a specified direction, was used to generate a horizontal derivative map for the Sirt Basin.

In Study area map of horizontal gravity gradient, anomalies were observed throughout. The map shows that the north-western and west and central parts of Sirt Basin (Fig.10) are strong horizontal gradient anomalies. The North-western part of study area (Fig.10, HD1) shows NW-SE strong gradient northwest of Al Hagfah Trough. In the central part of the basin can be divided into eight parts (Fig.10, HD2, HD3, HD4, HD4, HD6, HD7, HD8, HD9);the northern parts of the Al Jahamah Platform (HD2) and western part of Ajdabiya Trough (HD3); the eastern part of Ajdabiya Trough (HD5); the eastern part of Amal Platform (HD6) and southern part of Al Hagfah Trough(HD7); the central and southern part of the Al Wadayat Trough (HD8,HD9); most of trends showed many short anomalies of NW-SE orientation. The southwestern part of Sirt basin (Zallah Trough (HD10), Qattar Ride (HD11), southern part of Zallah Trough (HD12)) shows NNW-SSE trending was truncated by the E-W orientation. The south part of study area in the southern part of Zaltan Platform (HD 13) showed the N-S orientation. In the southeastern part of western Sirt basin and northern part of Hameimat Trough orientation the E-W trends (HD14), HD15), the eastern part of Amal Platform (HD16) strong E-W trends cuts with NNE-SSW changing to NW-SE trends

Isostatic Residual map: The isostatic residual anomaly was calculated by removing the long wavelength gravity effects caused by isostatic compensation i.e. variations in the crust/upper mantle boundary. The regional correction was calculated from topography using Airy's model of crustal compensation and subtracted from the Bouguer gravity anomaly to produce the isostatic residual gravity map of the study area. Theoretically, the isostatic residual should retain only the gravity effects from the upper crust to the surface. Note how the short wavelength character of the maps differs in the deep area related to crustal thinning accounted for to some degree in the isostatic correction. The low-pass filter map of the Bouguer gravity anomaly (Fig.11) with cut-off-wave number $(350 \mathrm{~km})$ was applied to obtain the regional gravity anomalies that were related and associated with deep sources. This filter was performed using the Fast Fourier Transform "FFT" technique in the frequency domain using Geosoft package software, 2009.

The Isostatic residual map of the area was characterized by a dominant northwest - southeast trend (Fig.12). The gravity seen on the isostatic anomaly might indicate a deepening of the basement, on the assumption that the isostatic correction has appropriately accounted for the deep crustal gravity effects. This is clearly evident in the Isostatic residual. The northwest part of Al Hagfah Trough, eastern part of Al Jahamah Platform, western part of Ajdabiya Trough and south-western part of Amal Platform showed NW-SE orientation trending anomalies. A strong NNW-SSE trending in the central part of the Zaltan Platform was truncated by the E-W trending structures in the western part of Hameimat Trough. This was consistent with the change of tectonic zones.

3D Euler deconvolution: Earlier studies have shown that the 3D Euler deconvolution method also delineates geological boundaries of magnetization or density and gives-estimates of depth to the basement. So far it has been applied primarily to magnetic data at Leeds by Neil (1990), Neil et al. (1991), Mukasa (1993) and Huang et al. (1994) who contributed further extensions and refinements. Few gravity applications have been reported but Marson and Klingele (1993) show some examples. In this study the application of this technique to regional gravity data was attempted.

The method was originally devised by Thompson (1982) for profile data and later developed for 3D gridded data by Reid et al. (1990).Euler's homogeneity equation may be written in the following form: 
$\left(\mathrm{x}-\mathrm{x}_{0}\right) \frac{\partial g}{\partial x}+\left(\mathrm{y}-\mathrm{y}_{0}\right) \frac{\partial g}{\partial y}+\left(\mathrm{z}-\mathrm{z}_{0}\right) \frac{\partial g}{\partial z}=\mathrm{N}(\mathrm{B}-\mathrm{g})$

Where $g$ is the magnetic or gravity anomaly detected at $(x, y, z)$ due to a body located at $\left(x_{0}, y_{0}, z_{0}\right)$. The 3D Euler deconvolution was carried out in the following sequence; Horizontal ( $x$ and $y$ directions) and first vertical derivative grids were prepared by use of the GEOSOFT programs GRIDHDRV and MAGMAP, respectively. These, together with the gravity grid, were then input to EULER with the chosen structural index $(\mathrm{SI})$ and window size (see below). $\mathrm{B}$ refers to the regional fie1d at $(\mathrm{x}, \mathrm{y})$ and $\mathrm{N}$ is a constant defined as the 'structural index' (SI), different for various geological structures. The SI has a geological meaning. $\mathrm{SI}=1$ is assuming edges source. It is something like a dyke, for example. In petroleum work, that is not too common. $\mathrm{SI}=0$ is assuming a contact of infinite depth extent. $\mathrm{SI}=0.5$ is some kind of the "in-between" state for blocks or contacts of finite depth extent (maybe thickness rough equal to the depth to top). This one is an approximation but it often gives useful depth (recommended by Reid et al. (1990).

Results from the application of the EULERW program with a window size of $8(32 \mathrm{~km} \times 32 \mathrm{~km})$ and an SI of 0.5 showed good "focusing" of solution positions. This window size was finally chosen as optimum for the data set.

The result of the Euler deconvolution of gravity and magnetic data are depicted in Fig. 13.and 14 respectively. Euler Deconvolution facilitated the identification of new faults as well as the mapping of known faults was also evident in the geological data. The interpretation of Euler solutions indicated that the NW-SE and NNW-SSE trends primarily characterized the structural setting of the Sirt basin. The depths of faults were observed to range from $<2.5$ to $>12.5 \mathrm{~km}$. These contacts, interpreted as faults, were plotted and statistically analyzed (fig. 12). The dominant trends in the Sirt basin (Table 6) indicated that four major fault patterns (NW-SE, NE-SW, E-W, and N-S) characterized the investigated area. The analysis showed that the dominant subsurface faults trend in the NE-SW direction, whereas the NW-SE trend was observed to be subordinate. Other directions with significant representation included N-S and E-W. The $\mathrm{N}-\mathrm{S}$ trend is more conspicuous, while the remaining directions are unimportant. Interpreted faults in the
NW-SE direction were the longest in the subsurface, followed by NE-SW faults, N-S faults, and finally E-W faults, which were the shortest interpreted faults in the subsurface of the investigated area.

These results were compared with the geological information in order to explain the relationship between surface and subsurface structures. A comparison of the estimated faults extracted from the geological map, horizontal derivative and Euler deconvolution from gravity and magnetic showed relative agreement with subsurface structures (Fig. 15). The ultimate appellation of these techniques should result in a more detailed and accurate geological interpretation. In particular, the comparison of such data has provided new opportunities for studying the tectonic evolution of the investigated area.

\section{RESULTS AND DISCUSSION}

The interpretation of gravity and magnetic data can be aided by the application of several filtering such as total horizontal derivative and Isostatic residual for Bouguer gravity map. The 3D Euler Deconvolution technique was used for gravity and magnetic data. These techniques were applied in this study with the principle aim to have better understanding on the regional tectonics and structures. The success of the various techniques often vary from one area to another, depending on a number of factors such as data quality, coverage and the type of geological features being imaged.

Bouguer gravity anomaly of Sirt basin was generally in good coverage and it showed gravity values between +49 and $-45 \mathrm{mGal}$. The Bouguer gravity map (Fig.7) indicated nine main positive and seven main negative trends; the nine positive areas were $P 1, P 2, P 3, P 4, P 5, P 6$, and $P 7$ in the northeastern, central and southeast parts of the areas as shown in figure 10 with a NW-SE trends, (P8) with trend E-W, (P9) with tend N-S. The main negative anomaly zones (N1-N5) were in the northwest, Central, south, southwest and southeast part of the study area trending NW-SE and was superposed by smaller N-S oriented anomalies, $(\mathrm{N} 6, \mathrm{~N} 7)$ with trends E-W. 
Am. J. Sci. Ind. Res., 2010, 1(3): 448-462

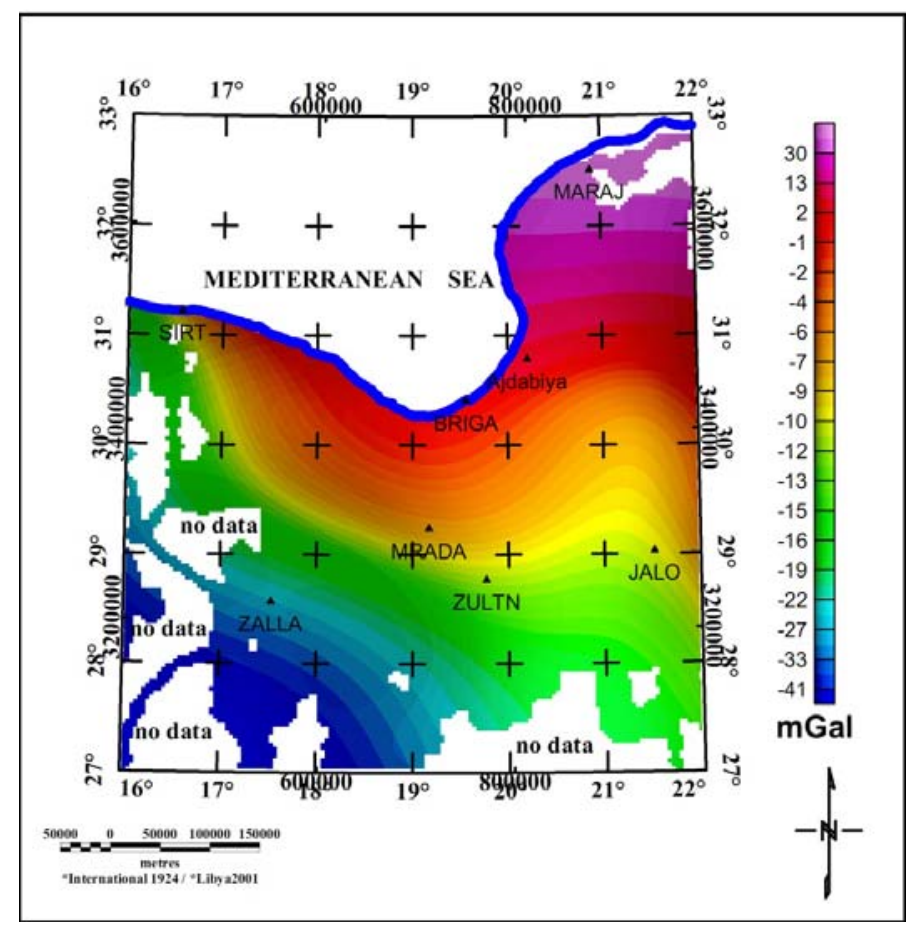

Fig.11 Regional Gravity Map of Sirt Basin using low pass filter $350 \mathrm{~km}$.

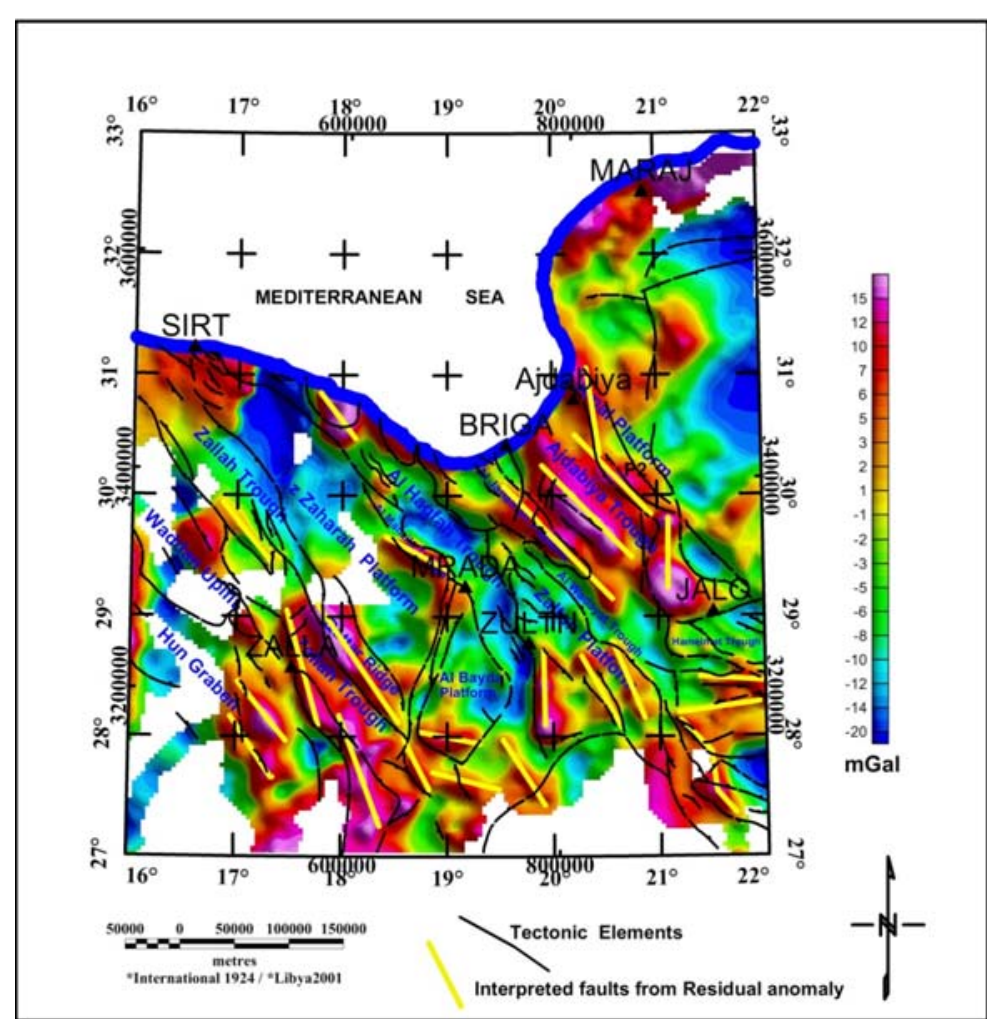

Fig. 12 Residual Bouguer gravity map of the Sirt Basin. 
Am. J. Sci. Ind. Res., 2010, 1(3): 448-462

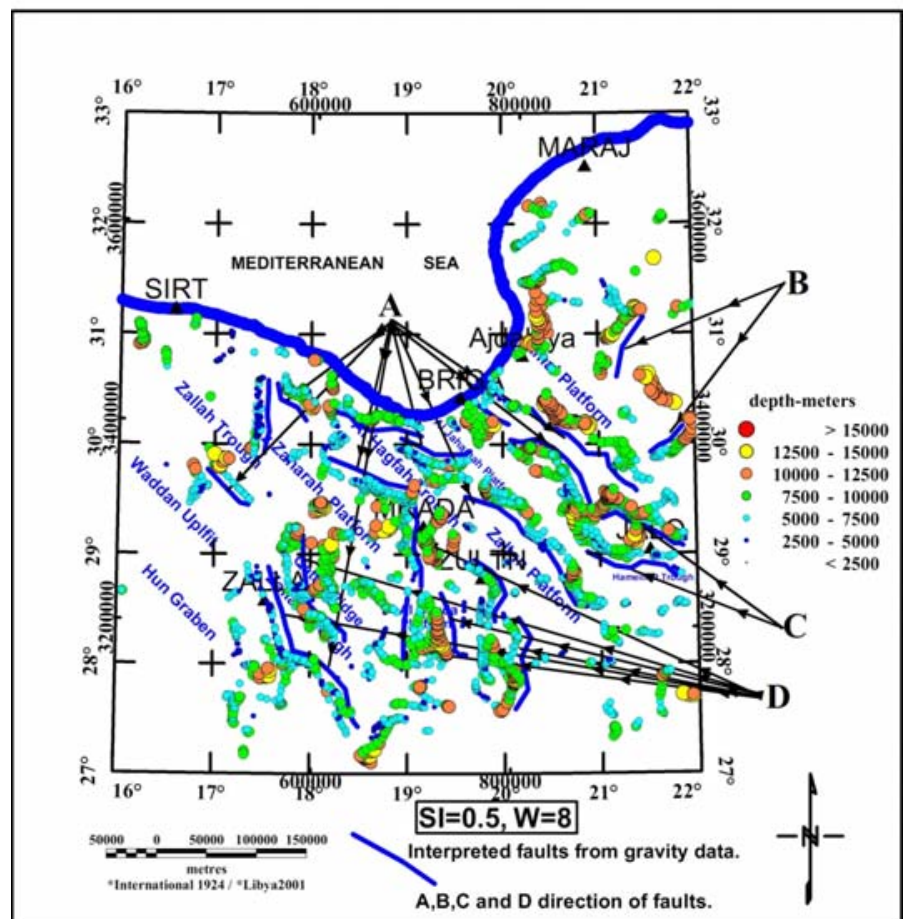

Fig.13 Euler deconvolution for Bouguer anomaly in the Sirt basin.

( $\mathrm{SI}=0.5, \mathrm{~W}=\mathbf{8}$, depth range $0-15000$ meters)

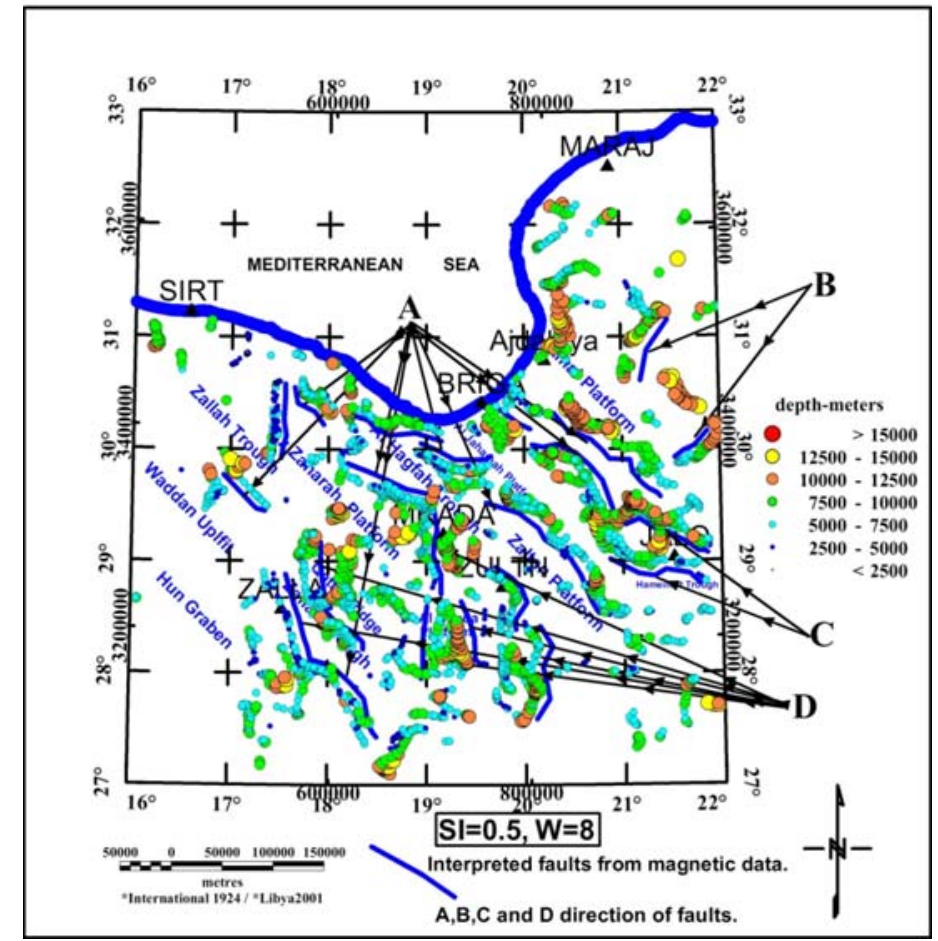

Fig.14 Euler deconvolution for Total Magnetic Intensity anomaly in the Sirt basin.

$(\mathrm{SI}=0.5, \mathrm{~W}=8$, depth range $0-15000$ meters) 


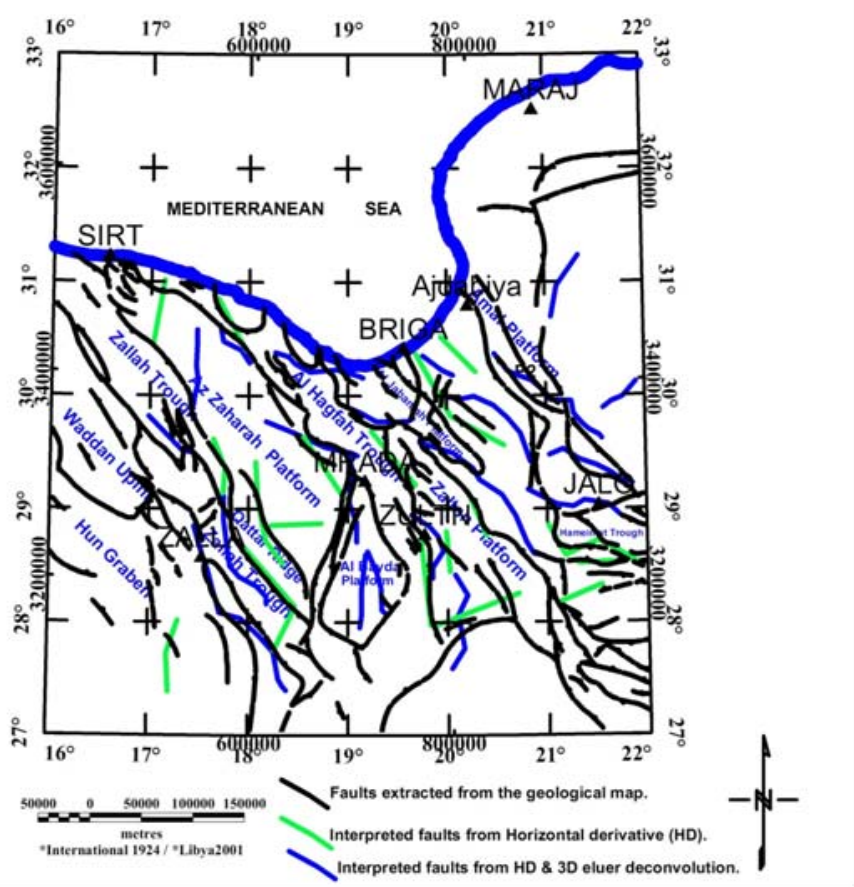

Fig.15 New tectonic map of Sirt Basin obtained faults extracted from: the geological map, gravity and magnetic data. Solid black lines are the faults from the geological map. Solid green lines are the interpreted faults from horizontal derivative map. Solid blue lines indicate the interpreted faults from horizontal derivative and 3 D Euler deconvolution map.

The Total Magnetic Intensity (TMI) map depicted in this study reflected the major tectonic features in the Sirt basin. The southwest part of Sirt basin showed the extensive NW-trending anomalies interpreted as represented belt of mid Jurassic to Early Cretaceous volcanic/intrusive complexes occupying the Sirt Basin and its extension to the northwest. The Sirt trough, Ajdabiya trough and Sarir troughs were marked by negative or low values anomaly, whereas the central, southern and eastern parts of Sirt basin were indicated by a regional positive high anomaly.

The RTP aeromagnetic anomaly map showed that both low and high frequency anomalies characterized the magnetic field in the study area. The elongated positive magnetic anomaly with a value of 174 NT was observed over the location of southwest study area. It was characterized by high frequency and high amplitude. Such magnetic anomaly is associated with metavolcanics which are mainly characterized by high magnetic susceptibilities.

The Isostatic residual map of the area was portrayed by a dominant northwest - southeast trend. The gravity seen on the isostatic anomaly might indicate a deepening of the basement, on the assumption that the isostatic correction had appropriately accounted for the deep crustal gravity effects. This was clearly evident in the Isostatic residual. The northeast and south-western parts of study area show NW-SE orientation trending anomalies. A strong NNE-SSW trending in the central part of the study area was abridged by the E-W trending structures in the southeastern and south-western parts of the study area. This was consistent with the change of tectonic zones.

In Study area, map of horizontal gravity gradient, anomalies were observed throughout. The map showed that the northwestern and west and central parts of Sirt Basin (Fig.8) indicated strong horizontal gradient anomalies. The Northwestern part of study area (Fig.8, HD1) showed NW-SE strong gradient. The central part of the basin can be divided into eight parts (Fig.8, HD2, HD3, HD4, HD4, HD6, HD7, HD8, HD9); the northern part area (HD2,HD3,HD4); the eastern part (HD5); the western part (HD6,HD7); the central part (HD8); the southern part (HD9) showed many short anomalies of NW-SE orientation. The southwestern part of Sirt basin (HD10, HD11, HD12) 
shows NNW-SSE trending truncated by the E-W orientation. The south part of study area (HD 13) potrayed the $\mathrm{N}-\mathrm{S}$ orientation. The eastern part of the study area orientation the E-W trends (HD14, HD15, HD16); the eastern part (HD16) strong E-W trends cuts with NNE-SSW changing to N-S trends.

The interpretation of gravity and magnetic data can be aided by the application of 3D Euler Deconvolution technique in the Sirt basin showed the depth $<2500>$ to $5000 \mathrm{~m}$ representing solutions in the lower part of the sedimentary cover, whereas solutions of 5000-7500 m representing structural features related to the upper part of the basement. Depth values of $7500-10000 \mathrm{~m}$ were critically indicative of deep solution effects, reflecting the deep part of the sediment. Deeper solutions between $10000-12500$ and < $15000 \mathrm{~m}>$ showed lower solutions structural boundaries in the study area. Depth values from $5000-7500 \mathrm{~m}$ and between 7500 $10000 \mathrm{~m}$ showed coherent structural boundaries in the sediment, especially in the western, central and eastern part of the study area (which was labeled as area A) where NW-SE, in the eastern part of study area where NE-SW (which was labeled area B) and $\mathrm{E}-\mathrm{W}$ ((labeled as area D) trends were observed, whereas in the $0-4000 \mathrm{~m}$ range no structural trends were clearly visible. The data gathered showed that structural elements became progressively more coherent with depth, especially from 5000m downwards. Thus, the E-W trend of area $D$ was an example of such development.

\section{CONCLUSION}

The Bouguer, Magnetic and RTP anomalies maps confirmed the known Sirt basin regional tectonic elements. Furthermore both maps indicate few possible wrench tectonics. The most domain and lineament was a right lateral wrench fault trending NW-SE which extended from the northern limit of Hameimat Trough crossing the north-central Ajdabiya Trough and grades away in the depression separating the Jahamah Platform from the Zaltan Platform. Ajdabiya Trough was $\mathrm{s}$ a complex series of depocentres with 2 main $\mathrm{N}$ trending graben in the north. $\mathrm{N}$-trending en echelon faults form the margin of the trough with the Amal Platform to the east. The presence of NW trending anomalies in the NE and E part of the Sirt basin was described as representing the NW Najd Fault System. The second possible wrenching was left lateral, which was oriented N-S to NNW-SSE affecting the southcentral Sirt Basin and possibly connecting the Abu Tumyan Sub-basin with Kotla Graben and died out in the Marada Trough. The western part of Sirt basin limit of the Hun Graben had not been well defined by the Bouguer and the residual gravity maps, possibly due to the lack of adequate data coverage. The gravity maps indicated shallow crustal zone along the present day coast lined, steeply dipping towards the offshore region. The Total horizontal derivative results of Gravity, 3D Euler Deconvolution of gravity and magnetic data magnetic anomalies produced features trending similar to the positions of tectonic and geological information from the Sirt basin. High gradient values delineated NNW-SSE to N-S and NW-SE trends which marked the faulted southwestern, southern, northern and central boundaries of the basin, respectively. New faults with orientations NNW-SSE along the southwestern flank of the Sirt basin were truncated by E-W faults dividing them into segments. Strong N-S lineaments occurred over the southern and Central part of study area and were well indicated by the 3D Euler Deconvolution. From this study the 3D Euler Deconvolution provided very useful information of the rift structures.

\section{ACKNOWLEDGMENTS:}

The authors express their gratitude to the National Oil Corporation in Libya (NOC), the Libyan Petroleum Institute (LPI), the Shell Exploration teams in Tripoli and Rijswijk for providing gravity, magnetic data and the information needed for this Paper. We would like to thank the School of Environment and Natural Resource Sciences, Faculty of Science and Technology, Universiti Kebangsaan Malaysia for giving us the opportunity to use the facilities.

\section{REFERENCES.}

Agar, R.A., 1986. The Bani Ghayy Group; sedimentation and volcanism in pull-apart grabens of the Najd strike-slip orogen, Saudi Arabian Shield. Precambrian Research, 31:3. pp 259-274.

Al Husseini. M.I., 2000. Origin of the Arabian Plate structures; Amar collision and Najd Rift. GeoArabia (Manama), 5:4.pp 527-542.

Anketell, J. M., 1996. Structural history of the Sirt Basin and its relationships to the Sabratah Basin and Cyrenaica Platform, Northern Libya, The Geology of Sirt Basin, Volume III, pp 57-87.

Ambrose, 2000. The geology and hydrocarbon habitat of the Sarir Sandstone, SE Sirt Basin, Libya: Journal of Petroleum Geology, v. 23, pp 165-192.

Baird, D.W., Aburawi, R.M., and Bailey, N.J.L., 1996. Geohistory and petroleum in the Central Sirt Basin. In: Salem MJ, El-Hawat AS, and Sbeta AM (editors), The geology of the Sirt Basin. Elsevier, Amsterdam: pp.3-56.

Barr, F.T. and Weegar, A.A., 1972. Stratigraphic nomenclature of the Sirte basin, Libya. Petrol. Explor. Soc. Libya, p179.

Cordell, L.,1979, Gravimetric expression on graben faulting in santa Fe country and the Espanola basin, New Mexico: 
Guidebo., 30th Filed conf., Santa Fe country, N.Mex. Geol. Soc., pp 59-64.

Cordell, L., and Grauch, V.J.S., 1985. Mapping basement magnetization zones from aeromagnetic data in the San Juan basin, New Mexico. The utility of regional gravity and magnetic anomaly rnaps, society of exploration geophysicists.

Duronio, P., and Colombi, L., 1983. Mesozoic rocks of Libya, Spec. Pap, Petroleum Exploration Society Libya, pp 1-12.

El Alami, M., 1996. Petrography and reservoir quality of the Lower Cretaceous Sandstone in the deep Mar Trough, Sirt Basin, in Salem, M.J., El-Hawat, A.S., and Sbeta, A.M., eds., The geology of Sirt Basin: Amsterdam, Elsevier, v. II, p. 309-322.

Essed, A. S., 1978. A reconnaissance Bouguer gravity map of Libya, M.Sc. thesis, Purdue University.

Geosoft, reference manual, 2009, software for Earth Sciences Geosoft INC., Toronto, Canada.

Getech and Dr Saad Z Jassim, 2000. Libya A Tectonic and Depth -to-Basement study using well, gravity and magnetic data, unpublished report, No G0030.

Ghori, K.A.R., and Mohammed, R.A., 1996. The application of petroleum generation modeling to the eastern Sirt Basin, Libya, in Salem, M.J., El-Hawat, A.S., and Sbeta, A.M., eds., The geology of Sirt Basin: Amsterdam, Elsevier, v. II,pp 529-540.

Goudarzi G. H., 1970. Geology and mineral resources of Libya: a reconnaissance. U.S. Geol. Surv. Prof. Paper no. 660, Washington, p 104.

Goudarzi, G.H., 1980, Structure-Libya, in Salem, M.S., and Busrewil, M.T., eds., The Geology of Libya: London, Academic Press, v. 3, pp 879-892.

Gumati, Y.D., and Schamel, S., 1988. Thermal maturation history of the Sirte basin, Libya: Journal of Petroleum Geology, v. 11, pp 205-218.

Hallett, D., 2002. Petroleum geology of Libya. Elsevier, Amsterdam, Netherlands.

Hallett, D., and El Ghoul, A., 1996. Oil and gas potential of the Deep Trough Areas in the Sirt Basin, Libya. In: Salem MJ, El-Hawat AS, and Sbeta AM (editors), The geology of the Sirt Basin. Elsevier, Amsterdam: pp 455-484.

Hassan, S., 2009, strata.geol.sc.edu/Libya-Hassan/Sirt-BasinLibya.html. Industrial Research Centre and Geological Research and Minerals Department, Libya, 1985. Geological map of Libya, scale 1:1,000,000. Esselte Maps Service, Stockholm, Sweden.

Klitzsch, E., 1963. Geology of the north-east flank of the Murzuq basin (Djebel Ben Ghnema- Dor El Gussa area). Revue de L'Institut Francais Du Petrole, pp 1411-1427.

Klitzsch, E., 1971. The structural development of parts of Africa since Cambrian time. In: Gray, C. (Editor),
Symposium on the geology of Libya, University of Libya, Tripoli. Pp 253-262.

Klitzsch, E., 1981. Lower Palaeozoic rocks of Libya, Egypt, and Sudan In: Lower Palaeozoic of the Middle East, Eastern and Southern Africa, and Antarctica (Ed Holland, C. H.) John Wiley \& Sons, pp 131-163.

Libyan Petroleum institute, and FrOG Tech, formerly FrOG Tech, formerly SRK Consulting, Energy Services Group, 2004. Libya Area Regional Study (LARS), unpublished report, Project Code: NO701.

MacGregor, D.S., and Moody, R.T.J., 1998. Mesozoic and Cenozoic petroleum systems of North Africa, in MacGregor, D.S., Moody, R.T.J., and Clark-Lowes, D.D., eds., Petroleum geology of North Africa: Geological Society, Special Publication 132, pp 201-216.

Mansour, A.T., and Magairhy, I.A., 1996. Petroleum geology and stratigraphy of the southeastern part of the Sirt Basin, Libya. In: Salem MJ, El-Hawat AS, and Sbeta AM (editors), The geology of the Sirt Basin. Elsevier, Amsterdam: pp 485-428.

Montgomery, S., 1994. Sirte Basin, North-Central Libya, prospects for the future: Petroleum Frontiers, Petroleum Information Corporation, v. 11, no. 1, 94 p.

Morgan M, Grocott J, and Moody R, 1998. The structural evolution of the Zaghouan- Ressas Structural Belt, northern Tunisia. In: Macgregor D, Moody R, and ClarkLowes D (editors), Petroleum Geology of North Africa . Geological Society, London: p.405-422.

Moritz, H., 1984.Geodetic reference system 1980,Bul. Geode'sique,v.58,pp 388-393. Parsons, M.B., Azgaar, A.M., and Curry, J.J., 1980. Hydrocarbon occurrences in the Sirte Basin, Libya, in Miall, A.D., ed.: Canadian Society Petroleum Geologists Memoir 6, pp 723- 732.

Roohi. M, 1996. First symposium of the sedimentary Basins of Libya: Geology of Sirt Basin vol.II, pp 323-336.

Saheel, A. S., 1995. An Integrated geophysical study in Murzuq Basin (Southwest Libya). M Phil Thesis, University of Leeds.

Sghair, A.M.A., and El -Alami, M .A., 1996. Depositional environment and diagenetic history of the Maragh Formation, NE Sirt Basin, Libya. In: The Geology of the Sirt Basin. (eds M.J. Salem, M.T. Busrewil, A.A.Misallati and M.A,Sola) Elsevier, Amsterdam, II, pp 263-271.

Stoeser, D.B., and Camp, V.E., 1985. Pan-African microplate accretion of the Arabian Shield. Geological Society of America Bulletin, 96:7. pp 817-826.

Suleiman, A. S., 1994. Geophysics of the rifts associated with the Sirt Basin (North Africa) and the Anadarco Basin (North America), Doctoral Dissertation, University of Texas at El Paso, pp 150.

Thomas, D., 1995. Exploration limited since 70s in Libya's Sirte basin. Oil and Gas Journal. 93(11): 99-104 